\title{
Sürdürülebilir Kalkınma Çağında Kurumların Sürdürülebilirlik Yaklaşımı: Oteller Üzerinden Bir Değerlendirme
}

\author{
Nesrin CANPOLAT* ${ }^{*}$ Ebru ÖZTÜRK ${ }^{* *}$
}

Öz

Sürdürülebilir kalkınma kurumların işleyişlerinde ekonomik, çevresel ve sosyal parametreler arasındaki bağlılığı hesaba katmaları gereken bir süreci ortaya koymaktadır. Bu bağlamda da günümüz sürdürülebilir kalkınma çağında kurumların sürdürülebilirlik yaklaşımı önem arz etmektedir. $\mathrm{Bu}$ çalışmada da kurumların sürdürülebilirlik yaklaşımları sürdürülebilir kalkınmanın temel hedeflerini bünyesinde toplayan sürdürülebilir kalkınmanın üç temel stratejik boyutu (ekonomik, çevresel ve sosyal) esasında ele alınmaktadır. Araştırmada anket yöntemi kullanılmaktadır, anket soruları literatür taraması sonucu elde edilen çalışmalardan ve Otellerin Sürdürülebilirlik Raporlarından yola çıkılarak yapılandırılmıştır. Sorular otellerin sürdürülebilir kalkınmanın ekonomik, çevresel ve sosyal boyutu temelinde attıkları adımlar hakkında ipuçları verecek şekilde hazırlanmıştır. Araştırmanın evrenini turizm sektöründe faaliyet gösteren otellerin yöneticileri oluşturmakta, örneklem ise Holidaycheck'in 2017 Yllının En Iyi Otelleri Listesi'ne Türkiye'den giren 19 otelin yöneticilerini kapsamaktadır. Otel yöneticilerinden elde edilen veriler otellerin sürdürülebilir kalkınmanın temel on yedi hedefi yönünde önemli adımlar attıklarını ortaya koymuştur.

Anahtar Kelimeler: Sürdürülebilirlik, Sürdürülebilir Kalkınma, Turizm, Sürdürülebilir Turizm, Holidaycheck, 


\title{
The Sustainability Approach of Institutions in the Age of Sustainable Development: An Evaluation on Hotels
}

\begin{abstract}
Sustainable development reveals a process in which institutions should take into account the relationship between economic, environmental and social parameters in their operations. In this context, institutions' sustainability approach is essential in our contemporary age of sustainable development. In this study, institutions' sustainability approaches are discussed based on the three basic strategic dimensions (economic, environmental and social) of sustainable development which include the basic aims of the sustainable development. Questionnaire method is used in the research and questionnaires are formed, based on the studies acquired as a result of literature survey and Sustainability Reports of Hotels. Questions were prepared as to give clues about the steps hotels take on the basis of economic, environmental and social dimensions in sustainable development. Population of the study involves the managers of hotels operating in tourism sector and sample contains the managers of 19 hotels that are listed in the Best Hotels List of 2017 in Holidaycheck. As a result of the data obtained from the hotel managers it was observed that hotels have taken important steps towards the basic seventeen aims of sustainable development.
\end{abstract}

Keywords: Sustainability, Sustainable Development, Tourism, Sustainable Tourism, Holidaycheck

\section{Giriş}

İkinci Dünya Savaşı sonrası yaşanan teknolojik, endüstriyel gelişmeler, kontrolsüz nüfus artışı ve tüketimin ön plana geçtiği bir kalkınma sürecini dikte eden hızlı kapitalist bir dönüşümü zorunlu kılmıştır. Bu durumun ise 1960'lı yıllarda ekolojik dengeyi bozduğu fark edilmeye bașlanmıştır.

1962 yılında Rachel Carson'un çevresel kirlenmeyi ele aldığı kitabı Silent Spring (Sessiz Bahar) adlı çalışma, büyük yankılar uyandırmış, dikkatleri mevcut sanayileşme süreçlerinin çevreye verdiği zararlar üzerinde yoğunlaştırmıştır. Ayrıca 1968 yılında kurulan Roma Kulübü'nün, Massachusetts Teknoloji Enstitüsü'ne yaptırdığı çalıșma, ekonomik gelişme ile çevre arasında güçlü bir ilişkinin olduğuna değinen, Ekonomik Büyümenin Sınırları (Limits to Growth) araştırması, 1972 yılında kitaplaştırılarak dikkatleri yeniden çevresel konulara çekmiștir. Bunu takiben dünyayı tehdit eden çevresel felaketlere dikkat çekmek için 1970 yılında UNESCO Projesi 22 Nisan Dünya Günü hayata geçirilmiștir (Oltmanns, 2008, Bozlağan, 2005, Özmehmet, 2012).

Dünyada özellikle de sanayileşmiş bölgelerde karşılaşılan çevresel sorunların etkisiyle 1970'li yıllarda gelișen çevre hareketinin kısa sürede daha bütüncül bir yaklaşıma dönüştüğü görülmektedir. Bu bağlamda, 5-16 Haziran 1972 tarihinde İsveç'in başkenti Stockholm'de Birleşmiş Milletler İnsani Çevre Konferansı (Stockholm 
Konferansı) düzenlenmiștir. Stockholm Konferansı ile çevre sorunları uluslararası alanın önemli bir sorunu olmuştur. Bu konferansın anısına her yll 5 Haziran Günü, bütün dünyada Çevre Günü olarak kutlanmaktadır. 1970'li yıllarda yoğun bir biçimde yaşanan ekolojik tartışmaların ana teması sürdürülebilirlik konusu olmuş, sürdürülebilirlik düşüncesi on yıl gibi bir süre içinde ulusal ve uluslararası çevre hareketlerinde önemli bir yer edinmiștir. Sürekli ve saldırgan kalkınma politikaları, yerini daha insani olarak nitelendirilebilecek sürdürülebilir kalkınma politikalarına bırakmaya başlamıștır. Konunun önemli olmaya başlamasından hareketle Birleşmiş Milletler öncülügünde Ocak 2016 'da on yedi tane temel Sürdürülebilir Kalkınma Hedefleri yürürlüğe sokulmuștur. Bunlar yoksulluğa son, açlığa son, sağlıklı bireyler, nitelikli eğitim, toplumsal cinsiyet eşitliği, temiz su ve sıhhi koşullar, erişilebilir temiz enerji, insana yakıșır iş ve ekonomik büyüme, sanayi yenilikçilik ve alt yapı, eșitsizliklerin azaltılması, sürdürülebilir şehir ve yaşam alanları, sorumlu tüketim ve üretim, iklim eylemi, sudaki yaşam, karasal yaşam, barıș ve adalet, hedefler için ortaklıklar şeklinde sıralanmaktadır. Bu maddelerde kısaca şunlar hedeflenmektedir: Yoksulluğa ve açlığa son dünya genelinin yeterli gida, temiz içme suyu ve sıhhi koşullara erişimini; sağlıklı bireyler herkesin genel sağlık hizmeti, güvenli ve erişilebilir ilaç ve aşıya kavuşmasını sağlamayı; nitelikli eğitim herkes için kapsayıcı ve nitelikli eğitimin başarılmasını;toplumsal cinsiyet eşitliği kadınlar ve kız çocuklarına karşı her türlü ayrımcılığın ortadan kaldırılmasını; temiz su ve sıhhi koşullar ormanlar, dağlar, sulak alanlar ve nehirler gibi suyla bağlantılı eko-sistemleri korumayı ve eski haline getirmeyi; erişilebilir temiz enerji güneş, rüzgar ve termal gibi temiz enerji kaynaklarına yatırım yapmayı; insana yakışır iş ve ekonomik büyüme daha yüksek verimlilik düzeyleri ve teknolojik yenilikleri teşvik etmeyi; sanayi yenilikçilik ve alt yapı toplu taşımacılık ve yenilenebilir enerji, yeni endüstriler, bilgi ve iletişim teknolojilerinde büyümeyi;eşitsizliklerin azaltılması cinsiyet, ırk ve etnik kökene bakılmaksızın herkesin ekonomik katılımının desteklenmesini; sürdürülebilir şehir ve yaşam alanları toplu taşımacılığa yatırım yapmayı, kamusal yeşil alanlar yaratmayı, kentsel planlama ve yönetimi hem katılımcı hem de kapsayıcı olacak şekilde iyileştirmeyi; sorumlu tüketim ve üretim ortak doğal kaynakların verimli yönetimini ve zehirli atık ve kirleticileri bertaraf etmeyi; iklim eylemi Dünya üzerindeki iklim değişikliğinin ağır etkilerini azaltmayı; sudaki yaşam deniz ve kıyı eko-sistemlerini sürdürülebilir biçimde yönetmeyi, kirlenmeden korumayı;karasal yaşam ormanlar, sulak alanlar, kurak alanlar ve dağlar gibi karasal eko-sistemleri korumayı ve eski haline getirmeyi; barış ve adalet şiddetin her biçimini önemli ölçüde azaltmayı, çatışma ve güvensizliğe kalıcı çözümler bulmayı: hedefler için ortaklıklar sürdürülebilir kalkınma hedefleri için küresel ortaklık ve işbirliğinin gerçekleştirilmesini ele almaktadır.

Sürdürülebilir kalkınma stratejisi de bu on yedi hedef temelinde ekonomik, sosyal ve çevresel anlamda üç süreç etrafında işlemektedir (http://www.tr.undp.org). Sürdürülebilir kalkınmanın ekonomik boyutu, mal ve hizmetleri doğal kaynakların aşırı tüketimini engelleyerek üreten sürdürülebilir bir sistemi anlatmaktadır. Çevresel boyutu ise kendi kaynaklarını yönetebilen ve çevreye zarar vermeden bunu yapan bir sistemi kastetmektedir. Sosyal boyutu ise gelirde, eğitimde, cinsiyette, rrkta, etnik kökende eşitliği gözeten, siyasi güvenilirliğin olduğu ve katılıma önem verilen bir sistemi anlatmaktadır. Sürdürülebilir kalkınma bu üç unsuru birbiriyle dengede tutma sürecidir. 
Diğer bir deyişle de kurumların işleyişlerinde ekonomik etkiden ziyade çevresel ve sosyal parametreler arasındaki bağlılığı hesaba katmaları gereken bir süreci anlatmaktadır (Kayaalp ve Toprak 2011, ss. 5-6; Bozlağan, 2005, ss. 1015; Matos ve Silvestre, 2013). Günümüz sürdürülebilir kalkınma çağında da kurumların sürdürülebilirlik yaklaşımı önem arz etmektedir.

Özellikle çevresel unsurlardan beslenen turizm alanındaki kurumların, işleyişlerinde ekonomik etkiden ziyade çevresel ve sosyal parametreler arasındaki bağlılığı özenle dikkate alması gerekmektedir. Bunun iki temel nedeni vardır: birincisi turizmin diğer sektörlere oranla çevresel unsurları daha çok kullanmasıdır. Çünkü çevre turistik talepleri etkileyen en önemli unsurlardan biridir. 2017 yılında Holidaycheck Web Sitesi'nde otellerde kalan tüketicilerin otellerle ilgili yorumları irdelendiğinde* de kalite, personel, çevre, yemek ve temizlik konularının yer aldığı görülmüștür. Sürdürülebilir turizm insanların elde edebilecekleri, kaliteli fiziksel çevre düzenlemelerini teşvik eden bir yaklașım olarak ele alındığında tüm bu unsurların sürdürülebilir turizm açısından teşvik edici sonuçlar getirebileceği söylenebilir.

Turizmin sosyal ve çevresel parametreler arasında bağ kurma zorunluluğunun ikinci nedeni ise özellikle kitlelerin seyahat etmeye başlamasıyla birlikte bir kitle turizminin oluşmasıdır. Bu kitlesel turizm çevre kalitesini olumsuz yönde etkilemektedir. Mevcut arazi kullanımının değişmesi ile bazı bölgelerde tarımsal nitelikli toprakların yok olması, bitki örtüsü ve doğal çevrenin tahribi, doğal çevreye uyumsuz yapılar ile kıyı şeritlerinin estetik yönden çirkinleşmesi ve işlevini yitirmesi, mevcut altyapının kaldıramayacağı kanalizasyon, çöp sorunu ve bu atıkların denize boşaltılmasıyla ortaya çıkan kirlilik, tarihi alanların ve sit alanlarının tahribi, sosyal yasam, adetlerde alışkanlıklarda değişiklikler ve bozulmalar gibi pek çok olumsuz durumu tetiklemektedir (Can, 2013, ss. 25). Turizm endüstrisindeki bu kavramların iki önemli kurucusu olan Bramwell \& Lane'e göre, sürdürülebilir turizm kısmen çevresel zararlar ve toplum ve geleneksel kültürler üzerindeki ciddi etkiler gibi birçok turizm konusuna yanit olarak olumsuz ve reaktif bir kavram olarak ortaya çlktı (Aktaran: Zolfani, Sedaghat, Maknoon,Zavadskas, 2015). Ancak Bramwell \& Lane "Sustainable Tourism: Contributing to the Debates" makalelerinde sürdürülebilirlik literatürünün esas olarak doğal kaynakların kullanımı üzerinde yoğunlaştığını ekonomik, sosyal ve politik konuların göz ardı edildiğini belirterek sürdürülebilir turizm kavramında bu konularında son derece önemli olduğuna değinmişlerdir (Bramwell \& Lane, 1999). Baum da bu görüşü destekler nitelikte sürdürülebilir turizmi ziyaretçilerin, endüstrinin, çevrenin ve ev sahibi toplulukların ihtiyaçlarını ele alan mevcut ve gelecekteki ekonomik, sosyal ve çevresel etkileri dikkate alan turizm olarak tanımlanmıştır (Baum,

\footnotetext{
* Holidaycheck 2017 yılının en iyi otellerini açıklamasında Türkiye'den listeye girmeyi başaran 19 otelle ilgili bu sitede yer alan tüketici yorumları içerik analizi yöntemi ile irdelenmiştir. Bu otellerin Holidaycheck listesine girebilmesi için 50 ve üzeri yorum sayısına ihtiyaç duyulmaktaydı. Bu nedenle her bir otel için yapılan 50 yorum ilk, orta ve sonlarda yer alan yorumlardan rastgele seçilerek içerik analizine tabi tutulmuştur. Bu inceleme sonrasında da yorumların yukarıda ortaya koyulan 5 kategori kalite, temizlik, çevre, yemek ve personel konuları temelinde yapılandırıldığı görülmüştür (Ebru Öztürk 2017 yılında Nesrin CANPOLAT danışmanlığında hazırladığı Seminer çalışmasında bu verileri ortaya koymuştur).
} 
2018). Tüm bunlar turizm sektörünü sürdürülebilir turizm üzerine düşünmeye sevk etmesi gereken konulardır.

$\mathrm{Bu}$ çalışmada buradan hareketle turizm sektöründe faaliyet gösteren otellerin sürdürülebilirlik yaklaşımlarını sürdürülebilir kalkınmanın ekonomik boyutu (mal ve hizmetleri doğal kaynakların aşırı tüketimini engelleyerek üreten sürdürülebilir bir sistem) ve çevresel boyutu (kendi kaynaklarını yönetebilen ve çevreye zarar vermeden bunu yapan bir sistem) temelinde ortaya koyma amacı gütmektedir. Bu çalışmada sosyal boyut yöneticilerin cinsiyet oranları, otellerin paydaşlarını bilgilendirme ve bilinçlendirme boyutları temelinde irdelenmiștir. Diğer sosyal boyut parametreleri ele alınmamıştır, bu parametreler başlı başına araștırılması gereken bir konudur ve ileride ayrı bir makale konusu olabilir.

\section{Literatür Taraması}

Geniş anlamda sürdürülebilirlik üzerine literatür kurumlar için oluşturulan ekonomik değerin ekolojik etkiyi sınırlayarak ve toplumsal olarak sorumlu bir şekilde faaliyet göstererek nasıl gerçekleştirileceği üzerine yoğunlaşmıştır (Loorbach ve Wijsman, 2013). Sürdürülebilir turizm konusunda literatür tarandığında ise uluslararası ve ulusal bazda birçok çalışmanın yapıldığı görülmektedir. Burada özellikle makalemizle bağlantılı olacağı düşünülen çalışmalara yer verilmiștir. Uluslararası literatürde özellikle Bramwel ve Lane'in bu kavram konusunda kayda değer çalışmaları vardır. Örneğin Bramwel \& Lane (1999) "Sustainable tourism: Contributing to the debates"; (2008) "Priorities in sustainable tourism research"; (2009) "Economic cycles, times of change and sustainable tourism"; (2010) "Sustainable tourism and the evolving roles of government planning"; (2011) "Crises, sustainable tourism and achieving critical understanding" (2012) "Towards innovation in sustainable tourism research?" ; (2013) "Getting from here to there: Systems change, behavioural change and sustainable tourism" araștırmalarından bazılarıdır. Yine Clarke'ın(1997) "A framework of approaches to sustainable tourism" adlı makalesi de sürdürülebilir turizm kavramının gelişimine dair çerçeve temelinde bir yaklaşım sunmaktadır. Ayrıca Ercan Sırakaya, Hwank Suk Chris Choi'nin "Sustainability indicators for managing community tourism" çalışması da topluluk turizmi gelişimini ölçmek için göstergeler geliştirdikleri bir araştırmadır. Bu araştırma sonucunda siyasi (32), sosyal (28), ekolojik (25), ekonomik (24), teknolojik (3) ve kültürel boyutlar (13) olmak üzere toplam 125 gösterge grubu geliştirilmiştir. Yine Godfrey (1998) “Attitudes towards 'sustainable tourism' in the UK: A view from local government" adlı makalesinde yerel yönetimlerde yer alan turizm müdürleri ile anket çalışması yapmıştır. Godfrey, kamu sektörü turizm müdürlerinin "sürdürülebilir turizm" ilkelerine yönelik tutumlarını incelediği makalesinde bu görevlilerin tutumlarının uygulama yaklaşımlarını etkilediği ve sürdürülebilir turizm kavramının uygulamadaki başarısına da etki ettiğini öne sürmüştür. Horobin ve Long (1996) ise "Sustainable tourism: The role of the small firm" adlı makalelerinde Yorkshire Dales Milli Parkı'ndaki küçük turizm firmalarının sahibi yöneticilere uyguladıkları anket çalışmasıyla yöneticilerin bu konudaki bilgi düzeylerini, 
sürdürülebilirliğe yönelik tutumlarını ve çevreyi korumak için aldıkları önlemleri ortaya koymuşlardır. Araştırma sonucunda sürdürülebilirliğin genel ilkelerine çok fazla sempati duyulmasına rağmen, "sürdürülebilirlik" ve "çevresel kaygı" terimleri arasında bilgi eksikliğinden kaynaklanan bir karışıklık olduğu tespit edilmiştir. Irandu (2006) da "Sustainable tourism development on Kenya's Coast: A hospitality sector view" makalesinde Kenya'nın kıyısındaki turizmin ne ölçüde sürdürülebilir olduğu konusunda görüşlerini değerlendirmek üzere 28 otel yöneticilerine ve çalışanlarına bir anket uygulaması gerçekleştirmiştir. Çalışma sonucunda kıyıdaki turizm gelişiminin bazı olumlu ve olumsuz etkileri ortaya koyulmuş, kıyılarda turizmden kaynaklanan kirlilik nedeniyle ciddi çevresel bozulmalara maruz kalındığı tespit edilmiștir. Kernel (2005) ise "Creating and implementing a model for sustainable development in tourism enterprises" adlı makalesinde Danimarka'nın bazı kentlerinde sürdürülebilir turizm gelişimi üzerine bir projenin 26 küçük ve orta ölçekli turizm işletmesinde nasıl ele alındığını işbirliği kuramını kullanarak analiz etmiştir. Santos ve Figueroa (2012) "Implementation of a sustainable business cycle: The case of a tourism project in Puerto Rico" çalışmasında bir turizm işletmesini örnek olay olarak almıştır. Bu çalışmada şirketin başkan yardımcısı ile ve mevcut belgelerden yola çıkılarak şirketin sürdürülebilirliği verimli bir şekilde yürüttüğü alanlar vurgulanmıştır.

Türkiye'de ise genel tablo şu şekildedir: Demirbulat ve Dinç yaptıkları Sürdürülebilir Turizm Konulu Lisansüstü Tezlerin Bibliyometrik Profili Araştırmalarında sürdürülebilir turizm ile ilgili 1987-2015 yılları arasında toplam 62 lisansüstü tez yapıldığını ortaya koymuşlardır. Bu tezlerin tamamını inceleyen araştırmacılar inceledikleri tezlerin 41'inin $(\% 66,1)$ yüksek lisans ve 21 'inin $(\% 33,9)$ doktora tezi olduğunu belirtmişlerdir (Demirbulat ve Dinç, 2017). Araştırmacılar bu tezlerin özetle şu konuları kapsadığını iler sürmüşlerdir: yüksek lisans tezleri sürdürülebilir destinasyon yönetimi ve planlaması, bir destinasyonda sürdürülebilir turizm gelişimi, konaklama işletmeleri ve sürdürülebilir turizm ilişkisi; bir destinasyonda sürdürülebilir turizm olanaklarının araştırılması; doktora tezleri ise sürdürülebilir destinasyon yönetimi ve planlaması; bir destinasyonda sürdürülebilir turizm olanaklarının araştırılması ve sürdürülebilir turizm gelişimi ile ilgili yazılmıștır (Demirbulat ve Dinç, 2017, ss. 27-28).

Yılmaz, Ünal ve Çakır'ın Sürdürülebilir Turizm Literatürü Üzerine Bir Değerlendirme: Türkiye Bağlamı adlı çalışmaları bir diğer sürdürülebilir turizm ile ilgili yapılmış bir alan araştırmasıdır. Bu araștırmaya göre sürdürülebilir Turizm ile ilgili 2000-2015 yılları arasında toplam 127 çalışma yapılmıştır. Bu çalışmaların 1'i sürdürülebilir Turizm Rehberi, 1'i Sürdürülebilir Turizm bülteni, 56'sı bildiri, 23'ü makale, 4'ü kitap, 25'i yüksek lisans tezi, 13'ü doktora tezi, 2'si proje ve 2'si Sürdürülebilir Turizm raporundan oluşmaktadır (Yılmaz, Ünal ve Çakır, 2015). 20152018 yılları arasında sürdürülebilir turizm ile ilgili yapılan tezler irdelendiğinde ise toplam 28 lisansüstü tez yazıldığı görülmüştür. Bu tezlerin 22'si yüksek lisans ve 6'sı ise doktora tezidir. Bu çalışmalar kısaca değerlendirildiğinde çalışmaların sürdürülebilir turizm stratejileri ve bu stratejilerin geliştirilmesi (Masara, 2015; Taşçıŏ̆lu, 2016; Karadağ, 2016); Sürdürülebilir turizm kapsamında doğal ve sosyal kültürel varlıkların değerlendirilmesi ve korunması (Erdoğan, 2015; Balık 2015; Serçek, 2015, Er, 2016; 
Sağıroğlu, 2016); sürdürülebilir turizm bağlamında taşıma kapasitesi (Sınmaz, 2016; Öcal, 2017; Erdemir, 2018); sürdürülebilir turizm kapsamında yaratıcı turizm, sosyal turizm ( Güven, 2016, Sonuç 2016); sürdürülebilir turizm ve sertifikalandırma (Yılmaz, 2017, Satar, 2016); sürdürülebilir turizm ve yerel halkın turizmin etkilerine yaklaşımı (Bulut, 2015); sürdürülebilir turizm planlaması ve bölgesel ekonomik kalkınma (Baran, 2015); sürdürülebilir turizm, yerel değerler ile turist tatmini (Uğur, 2015); turizm destinasyonları için sürdürülebilir turizmin önemi (Kıran, 2017); Türkiye'de STK'ların sürdürülebilir turizmdeki rolü (Gökçetin, 2015); SWOT temelli bulanık çok kriterli karar verme yaklaşımıyla Türkiye için sürdürülebilir turizmin stratejik analizi (Torbalı, 2016); sürdürülebilir turizm çerçevesinde engelsiz turizm potansiyelinin incelenmesi (Kahveci 2016); sürdürülebilir turizm, yerel değerler ile turist tatmini arasındaki yapısal ilişkilerin incelenmesi (Uğur, 2015); sürdürülebilir turizm kapsamında taşıma kapasitesi: Foça'da kullanıcı memnuniyeti (Sınmaz, 2016); sürdürülebilir turizm kalkınması sürecinin turizm paydaşları tarafından değerlendirilmesi (Hatırnaz, 2016); sürdürülebilir turizm değerleri kapsamında yerel halkın golf turizmi algısı (Gündüz, 2017); sürdürülebilir turizm kapsamında Kapadokya'ya gelen yabancı turistlerin Türkiye'ye bakışı ve güvenlik algısı (Uslu, 2017) gibi konular araștırılmıştır. Bu çalışmada da otellerde görevli yöneticilerin anketlere verecekleri yanıtlardan turizm sektöründe faaliyet gösteren otellerin sürdürülebilirlik açısından analiz edilmesi ve otellerin sürdürülebilirlik bilinçlerinin ortaya koyulması amaçlanmaktadır.

\section{Yöntem}

Araștırmada anket yöntemi kullanılmıștır. Anket soruları literatür taraması sonucu elde edilen çalışmalardan, Canpolat ve diğerlerinin 2014 yılında Küresel İlkeler Sözleşmesine Üye Türk Şirketleri'nin 30'unun Sürdürülebilirlik Raporlarını incelemeleri *sonucu ortaya çıkardıkları verilerden ve Otellerin Sürdürülebilirlik Raporlarından yola çıkılarak oluşturulmuştur. Meslektaşlardan alınan görüşlerle yüzey geçerliliği, uzmanlardan alınan görüşlerle kapsam geçerliliği ve Cronbach Alpha değerleri hesaplanmıştır. Anketlerdeki değişkenleri ölçmek amacıyla, katılımcılara sorulan soruların birbiriyle tutarlı olup olmadıklarını açıklamak ve yeterliliklerini ortaya koymak için yapılan güvenilirlik analizlerinden biri Cronbach Alpha katsayısıdır. Bu katsayı 0-1 arasında değişmektedir. Katsayı 1'e yaklaşınca uyumluluk ve tutarlılık oranının yüksek olduğu sonucu çlkarılmaktadır (İslamoğlu, 2009: 130 Çelmeli, 2012: 52: Aktaran Çengel, 2013:155). Otel yöneticilerinin otellerin sürdürülebilirlik adımlarına bakışlarına yönelik bulgularda 38 madde için analiz yapıldığında elde edilen Cronbach's Alpha değerinin 0,968 olduğu görülmektedir.

Anket kişisel bilgiler ve otelin nitelikleri adı altında iki bölümden oluşmaktadır. Kişisel bilgiler bölümünde kapalı uçlu 7 soru otellerin nitelikleri bölümünde ise otellerin sürdürülebilirlik yaklaşımlarını ortaya koyacağı düşünülen 5'li likert ölçeği ile

\footnotetext{
* Canpolat Nesrin vd. (2015) “Sürdürülebilir Kalkınma Çağında Kurumsal İletişim”Çağdaş Pazarlamada Yeni Yaklașımlar, Ed. Murat Toksarı ve Murat Akın, Paradigma Akademi Yayınları
} 
düzenlenmiş 38 madde bulunmaktadır. Bu anket 2017 yllında Holidaycheck listesine* Türkiye'den giren 19 otele oteldeki her kademedeki yöneticilerin yanıtlaması için gönderilmiştir. Anketleri yanıtlamaları için otellerle görüşmeler 15 Şubat 2018'de başlamış 20 Mayıs 2018 tarihine kadar iletişim süreci devam etmiştir. İletişim, facebook, e-posta ve telefon görüşmeleri aracılığıyla yapılmıştır.

\subsection{Evren ve örneklem}

Araștırmanın evrenini turizm sektöründe faaliyet gösteren otellerin yöneticileri oluşturmakta, örneklem ise Holidaycheck'in 2017 Yılının En Iyi Otelleri Listesi'ne Türkiye'den giren 19 otelin yöneticilerini kapsamaktadır. 19 otel arasından sadece 12 otel ankete katılmayı kabul etmiştir. Anketler 12 otelin 38 yöneticisi tarafından yanıtlanmıştır. Cinsiyetler ele alındığında katılımcıların \%42,1'i (16) kadın, \%57,9'u (22) erkektir, erkek katılımcıların daha fazla olduğu görülmektedir. Katılımcıların yaş dağılımı irdelendiğinde yöneticilerin çoğunluğunun 36 yaş ve üzeri $(\% 63,2)$ olduğu dikkat çekmektedir. Bunu sırasıyla 31-35 yaş aralığı \%23,7, 25-30 yaş aralığı \%10,5, 18 24 yaş aralığı \%2,6 takip etmektedir. Bu sonuçlardan yola çıkılarak üst pozisyonda yer alabilmek için yaşın, tecrübenin ve emeğin önemli bir unsur olduğu söylenebilir. Katılımcıların \%71,1'i evli, \%28,9'u ise bekardır. Katılımclların \%65,8'i lisans mezunu, $\% 26,3$ 'ü lise mezunu,

\%5,3'ü ilkokul mezunu, \%2,6'sı ise yüksek lisans mezunudur. Buna göre katılımcıların çoğunluğu yükseköğretim düzeyinde eğitimli kişilerdir.Katılımcıların $\% 18,4$ 'ü ön büro müdürü, $\% 13,2$ 'si insan kaynakları müdürü, $\% 10,5$ 'i kat hizmetleri yöneticisi, \%7,9'u misafir iliş̧kileri müdürü, \%5,3’ü genel müdür yardımcısı, $\% 5,3$ 'ü gece müdürü, \%5,3'ü teknik servis müdürüdür. Bunları sırasıyla kalite müdürü, satış ve pazarlama müdürü, mutfak şefi, mühendis, mimar ve santral operatörü pozisyonundaki kişiler takip etmektedir. 7 katılımcı ise mesleklerini belirtmemiştir. Katılımcıların görev yıllarına ilişkin bulgular irdelendiğinde \%57,9'u ifade ettiği görevde 13 yllan fazla çalışmaktadır. Ayrıca \%15,8'i 5-8 yıl, \%13,2'si 9-12 yll, \% 7,9'u 1-4 yıl arasında görevinde çalışmış kişilerdir. Bu oranlar katılımclların tecrübeli kişilerden oluştuğunu ortaya koymaktadır. Soruları yanıtlayanların şu an bağlı bulundukları kurumda çalıştıkları süre ele alındığında katılımcıların \%39,5'i 13 yıldan fazla, \%18,4'ü 1-4 yıl, \%18,4 5-8 yll, \%15,8'i 1 yldan az, \%5,3'ü 9-12 yıldır bu kurumda çalıştıkları görülmektedir. 9 yıl üstü çalışan katılımcıların oranları toplandığında yüzde 44 yapmaktadır. $\mathrm{Bu}$ oranlar katılımcıların kurumda bir geçmişlerinin olduğunu göstermektedir.

\subsection{Verilerin analizi}

Elde edilen veriler SPSS programı kullanılarak değerlendirilmiş ve verilere tanımlayıcı analiz yüzde yapılmıştır.

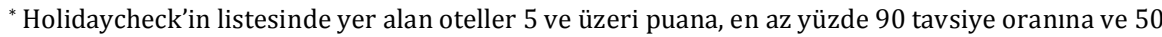
misafir yorumuna sahip tesislerin arasından seçilmiştir.
} 


\section{Bulgular}

Elde edilen bulgular otellerin sürdürülebilirlik yaklaşımlarını ortaya koymaktadır. Tablo

1 'deki veriler otellerin sürdürülebilir kalkınmanın ekonomik boyutu temelinde yaptıkları eylemler konusunda ipuçları vermektedir.

\begin{tabular}{|c|c|c|c|c|c|c|}
\hline Ekonomik Boyut & 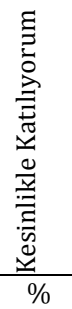 & 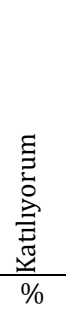 & 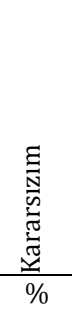 & 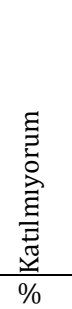 & 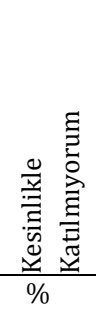 & $\sum_{\substack{1 \\
0}}$ \\
\hline $\begin{array}{l}\text { Otelimiz çevre mevzuatı gerekliliklerine } \\
\text { uyarak çevre koruma bilincine sahiptir. }\end{array}$ & 84,2 & 13,2 & 2,6 & - & - & $\% 100$ \\
\hline $\begin{array}{l}\text { Otelde kullanılan malzemenin tehlikeli } \\
\text { madde içermemesine özen gösterilmektedir. }\end{array}$ & 68,4 & 18,4 & 13,2 & - & - & $\% 100$ \\
\hline $\begin{array}{l}\text { Tehlikeli madde içeren malzemeler bertaraf } \\
\text { edilmektedir. }\end{array}$ & 78,9 & 18,4 & 2,6 & - & - & $\% 100$ \\
\hline $\begin{array}{l}\text { Ürün satın alınırken enerji verimliliğine } \\
\text { dikkat edilmektedir. }\end{array}$ & 68,4 & 23,7 & 7,9 & - & - & $\% 100$ \\
\hline $\begin{array}{l}\text { Otelde bulunan ve satın alınan tüm } \\
\text { elektronik ürünlerin enerji tasarruflu } \\
\text { olmasına dikkat edilmiştir. }\end{array}$ & 60,5 & 23,7 & 5,3 & 10,5 & - & $\% 100$ \\
\hline $\begin{array}{l}\text { Otelimizde çevre konusunda sürekli } \\
\text { iyileștirme ilkesi temelinde elektrik, su, yakıt } \\
\text { ve diğer birimlerde tasarruf yapılmaktadır }\end{array}$ & 68,4 & 23,7 & 2,6 & 5,3 & - & $\% 100$ \\
\hline $\begin{array}{l}\text { Otelde enerji ve su tasarrufu sistemleri } \\
\text { kullanılmaktadır. }\end{array}$ & 71,1 & 21,1 & 5,3 & 2,6 & - & $\% 100$ \\
\hline $\begin{array}{l}\text { Odalarda balkon kapısı açıldığı zaman ısıtma- } \\
\text { soğutma cihazlarını devre dışı bırakan } \\
\text { sistemler mevcuttur. }\end{array}$ & 65,8 & 13,2 & - & 15,8 & 5,3 & $\% 100$ \\
\hline $\begin{array}{l}\text { Otelde enerji tasarruflu ampuller ya da LED } \\
\text { ışıklar kullanılmaktadır. }\end{array}$ & 68,4 & 28,9 & 2,6 & - & - & $\% 100$ \\
\hline $\begin{array}{l}\text { Işıklandırma sistemi harekete duyarlı hale } \\
\text { getirilip kimsenin bulunmadığı alanlarda } \\
\text { hareket olmadığı için ışıkların otomatik } \\
\text { olarak sönmesi sağlanmaktadır }\end{array}$ & 50,0 & 31,6 & 13,2 & 5,3 & - & $\% 100$ \\
\hline $\begin{array}{l}\text { Misafirler odalarından ayrıldıklarında } \\
\text { elektrik sistemlerinin otomatik olarak } \\
\text { kapanmasını sağlayan kart sistemleri } \\
\text { kullanılmaktadır. }\end{array}$ & 84,2 & 13,2 & 2,6 & - & - & $\% 100$ \\
\hline
\end{tabular}

Tablo 1. Sürdürülebilir Kalkınmanın Ekonomik Boyutu 
Otel yöneticileri, çalıștıkları otelin çevre mevzuatı gerekliliklerine uyarak çevre koruma ve bilincine sahiptir sorusuna \%84,2'le kesinlikle katılıyorum, \%13,2 ile katılıyorum yanıtını vermiștir. Yüzde \%2,6’sı ise kararsız kalmıștır. Bu sonuçlardan otellerin genel olarak çevre bilincine sahip oldukları sonucu çlkarılabilir. Otelde kullanılan her türlü malzemenin tehlikeli madde içermemesine özen gösterilmektedir sorusuna katılımcılar \%68,4 kesinlikle katılıyorum, \%18,4 katılıyorum, \% 13,2 kararsızım şeklinde yanıtlamışlardır. Bu veriler otellerin kullandıkları her türlü malzemenin içerisinde tehlikeli madde barındırmamasına dikkat ettikleri varsayımını doğrular niteliktedir. Tehlikeli madde içeren malzemeler bertaraf edilmektedir sorusuna katılımcılar \%78,9 kesinlikle katılıyorum, \%18,4 katılıyorum ve \%2,6 kararsızım şeklinde yanıt vermişlerdir. Bu bağlamda da tehlikeli madde içeren malzemelerin bertaraf edildiği söylenebilir.

Ürün satın alınırken enerji verimliliğine dikkat edilmektedir sorusunu katılımcılar \%68,4 kesinlikle katılıorum, \%23,7 katılıorum, \%7,9 kararsızım olarak yanıtlamışlardır. Bu veriler otellerin ürün satın alınırken enerji verimliliğine dikkat ettiklerini ortaya koymaktadır. Otelde bulunan ve satın alınan tüm elektronik ürünlerin enerji tasarruflu olmasına dikkat edilmiştir sorusuna katılımclların \%60,5'i kesinlikle katılıyorum, \%23,7'si katılıyorum, \%5,3'ü kararsızım cevabını verirken , \%10,5'i ise katılmıyorum cevabını vermiştir. Tabloda anket sorusuna ilişkin yanıtlara bakıldığında birkaç cevap dıșında otelde kullanılan elektronik ürünlerin enerji tasarruflu olmasına dikkat edildiği görülmektedir. Otelimizde çevre konusunda sürekli iyileştirme ilkesi temelinde elektrik, su, yakıt ve diğer birimlerle de en iyi tasarruf yapılmaktadır"sorusuna çalışanların \%68,4'ü kesinlikle katılıyorum, \%23,7'si katılıyorum, \%2,6'sı kararsızım, \%5,3'ü ise katılmıyorum yanıtını vermiştir. Bu bağlamda otellerin tasarruf konusunda duyarlılığa sahip olduğu söylenebilir. Odalarda balkon kapısı açıldığı zaman ısıtmasoğutma cihazlarını devre dışı bırakan sistemler mevcuttur sorusuna katılımcıların \%65,8'i kesinlikle katılıyorum, \%13,2'si katılıyorum ve \%15,8'i katılmıyorum, \%5,3'ü kesinlikle katılmıyorum șeklinde yanıt vermiștir. Bu veriler sonucu otellerde isıtmasoğutma cihazlarını devre dışı bırakan sistemlerin mevcut olduğu anlaşılmaktadır.

Otelde enerji tasarruflu ampuller ya da LED ışılklar kullanılmaktadır sorusuna katılımcıların \%68,4'ü kesinlikle katılıyorum, \%28,9'u katılıyorum ve \%2,6'sı kararsızım yanıtını vermiştir. Bu yüksek oranlar otellerin enerji tasarruflu ampuller ya da LED ışıklar kullandığını ortaya koymaktadır. Işıklandırma sistemi harekete duyarlı hale getirilip kimsenin bulunmadığı alanlarda hareket olmadı̆̆ı için ışıkların otomatik olarak sönmesi sağlanmaktadır sorusuna katılımcıların \%50,0'si kesinlikle katılıyorum, \%31,6'sı katılıyorum, \%13,2'si kararsızım, \%5,3'ü ise katılmıyorum şeklinde yanıtlamıştır. $\mathrm{Bu}$ verilerden otellerin çoğunun bu konuda duyarlı hareket ettiği söylenebilir. Misafirler odalarından ayrıldıklarında elektrik sistemlerinin otomatik olarak kapanmasını sağlayan kart sistemleri kullanılmaktadır sorusuna katılımcıların \%84,2'si kesinlikle katılıyorum, \%13,2 si katılıyorum, \%2,6'sı kararsızım demiştir. Bu veriler de otellerin bu konuda hayli yol kat ettiğini göstermektedir. Ayrıca yapılan bu uygulamalar otellerin sürdürülebilir kalkınma hedeflerinden sorumlu tüketim ve üretim kalkınma hedefleri yönünde çalıștıklarını göstermektedir. Otellerde sürdürülebilir kalkınmanın çevresel boyutu hakkında ise şu sonuçlar elde edilmiştir. 


\begin{tabular}{|c|c|c|c|c|c|c|}
\hline Çevresel Boyut & 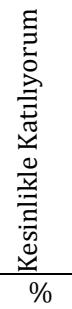 & 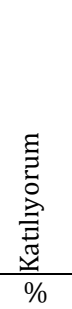 & 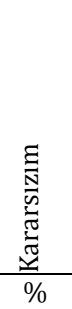 & 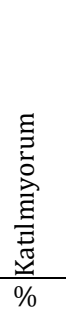 & 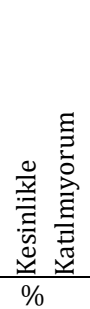 & $\sum_{\substack{\vdots \\
\vdots}}$ \\
\hline $\begin{array}{l}\text { Otelin sıcak su ihtiyacının giderilmesinde } \\
\text { güneș enerjisinden faydalanılmaktadır. }\end{array}$ & 39,5 & 36,8 & 5,3 & 7,9 & 10,5 & $\% 100$ \\
\hline $\begin{array}{l}\text { Bahçe sulamalarında fiskiye ve damlama } \\
\text { sistemleri kullanılarak suyun daha az } \\
\text { kullanılması sağlanmaktadır }\end{array}$ & 68,4 & 18,4 & - & 10,5 & 2,6 & $\% 100$ \\
\hline $\begin{array}{l}\text { Kâğıt tüketimini azaltmak için yazışmalar ve } \\
\text { duyurular elektronik ortam yoluyla } \\
\text { yapılmaktadır. }\end{array}$ & 63,2 & 28,9 & 5,3 & 2,6 & - & $\% 100$ \\
\hline $\begin{array}{l}\text { Atıklar kaynağında ayrılıp geri dönüşüme } \\
\text { kazandırılmaktadır. }\end{array}$ & 76,3 & 21,1 & 2,6 & - & - & $\% 100$ \\
\hline $\begin{array}{l}\text { Tehlikeli atık oluşumuna neden olacak } \\
\text { sistemler azaltılmaya çalışılmaktadır. }\end{array}$ & 60,5 & 26,3 & 7,9 & 5,3 & - & $\% 100$ \\
\hline $\begin{array}{l}\text { Oluşan atıklar hem çalışanların hem de } \\
\text { misafirlerin desteği ile kâğıt, plastik, metal } \\
\text { veya cam olarak ayrıştırılmaktadır. }\end{array}$ & 57,9 & 36,8 & 5,3 & - & - & $\% 100$ \\
\hline $\begin{array}{l}\text { Tüm atık sular arıtılarak deşarj edilmekte ve } \\
\text { kanalizasyon sistemine gönderilmektedir. }\end{array}$ & 55,3 & 26,3 & 5,3 & - & 13,2 & $\% 100$ \\
\hline $\begin{array}{l}\text { Misafirlerin atıkları ayrıştırabilmeleri için } \\
\text { yeterli miktarda çöp kutuları yerleştirilmiştir. }\end{array}$ & 65,8 & 18,4 & 13,2 & - & 2,6 & $\% 100$ \\
\hline $\begin{array}{l}\text { Otel içerisinde çeşitli alanlarda atık pil } \\
\text { kutuları mevcuttur. }\end{array}$ & 73,7 & 18,4 & - & - & 7,9 & $\% 100$ \\
\hline $\begin{array}{l}\text { Karbon salınımını azaltmak amacıyla satın } \\
\text { alımlar mümkün olduğunca yakın bölgelerden } \\
\text { yapılmaktadır. }\end{array}$ & 52,6 & 44,7 & 2,6 & - & - & $\% 100$ \\
\hline $\begin{array}{l}\text { Karbon salınımını azaltmak amacıyla bisiklet } \\
\text { kiralama imkânı sağlanmaktadır. }\end{array}$ & 39,5 & 23,7 & 10,5 & 23,7 & 2,6 & $\% 100$ \\
\hline Daha az karbon enerjileri tercih edilmektedir. & 60,5 & 18,4 & 21,1 & - & - & $\% 100$ \\
\hline $\begin{array}{l}\text { Çevreye en az zarar veren teknoloji } \\
\text { kullanılmaktadır. }\end{array}$ & 65,8 & 23,7 & 7,9 & 2,6 & - & $\% 100$ \\
\hline $\begin{array}{l}\text { Çevreye zarar vermemek için ağaç kesimi } \\
\text { yapılmamaktadır. }\end{array}$ & 65,8 & 26,3 & 7,9 & - & - & $\% 100$ \\
\hline $\begin{array}{l}\text { Plajda yeterli sayıda çöp kutusu ve atık } \\
\text { konteynırı bulundurulmakta düzenli } \\
\text { kontrolleri yapılmaktadır. }\end{array}$ & 76,3 & 23,7 & - & - & - & $\% 100$ \\
\hline Deniz dip temizliği yapılmaktadır. & 47,4 & 26,3 & 10,5 & 2,6 & 13,2 & $\% 100$ \\
\hline
\end{tabular}

Tablo 2. Sürdürülebilir Kalkınmanın Çevresel Boyutu 
Otelin sıcak su ihtiyacının çoğu güneş enerjisinden sağlanmaktadır sorusuna katılımcıların \%39,5'i kesinlikle katılıyorum, \% 36,8'i katılıyorum, \%5,3'ü kararsızım, \%7,9'u katılmıyorum, \%10,5'i kesinlikle katılmıyorum yanıtını vermiştir. Bu verilerden otellerin sıcak su ihtiyacını güneş enerjisinden elde ettiği sonucu çıkarılabilir. Bahçe sulamalarında fiskiye ve damlama sistemleri kullanılarak suyun daha az kullanılması sağlanmaktadır sorusuna katılımcıların \%68,4'ü kesinlikle katılıyorum, \%18,4'ü katılıyorum, \%10,5'i katılmıyorum, \%2,6'sı ise kesinlikle katılmıyorum yanıtını vermiştir. Kağıt tüketimini azaltmak için yazışmalar ve duyurular elektronik ortam yoluyla yapılmaktadır sorusuna katılımclların \%63,2'si kesinlikle katılıyorum, \%28,9'u katılıyorum, \%5,3'ü kararsızım, \%2,6'sı katılmıyorum demiştir. Bu verilerden anlaşılacağı üzere otellerin kağıt tüketimini azaltmak için yazışmalarını mail yoluyla yaptıkları ve yeterli duyarlılığı gösterdikleri ortaya çıkmaktadır.

Atıklar kaynağında ayrılıp geri dönüşüme kazandırılmaktadır sorusuna katılımcılarsın \%76,3'ü kesinlikle katılıyorum, \%21,1'i katılıyorum ve \%2,6'sı kararsızım yanıtını vermiştir. Bu tablo otellerin geri dönüşüme gereken hassasiyeti gösterdiğini ve bu konuda yeterli duyarlılığa sahip olduğunu ortaya koymaktadır. Tehlikeli atık oluşumuna neden olacak sistemler otelimizde azaltılmaya çalışllmaktadır sorusuna katılımcıların \%60,5'i kesinlikle katılıyorum, \%26,3'ü katılıyorum, \%7,9'u kararsızım, \%5,3'ü katılmıyorum yanıtını vermiştir. Bu oranlar otellerin çevre için verilecek zararı minimize etmek için tehlikeli atık oluşumuna neden olacak sistemler yönünde çalışma yaptıklarını ortaya koyabilir. Oluşan atıklar hem çalışanların hem de misafirlerin desteği ile kağıt, plastik, metal veya cam olarak ayrıştırılmaktadır sorusuna katılımcıların \%57,9’u kesinlikle katılıyorum, \%36,8'i katılıyorum ve \%5,3'ü kararsızım cevabını vermiștir. Veriler değerlendirildiğinde otellerin oluşan atıkları doğaya geri kazandırmayı amaç edindikleri görülmektedir. Tüm atık sular arıtılarak deşarj edilmekte ve kanalizasyon sistemine gönderilmektedir sorusuna katılımcların \%55,3'ü kesinlikle katılıyorum, \%26,3'ü katılıyorum, \%5,3'ü kararsızım, \%13,2'si ise kesinlikle katılmıyorum demiştir. Veriler değerlendirildiğinde otellerin bu konuda duyarlı hareket ettiği söylenebilir. Misafirlerin atıkları ayrıştırabilmeleri için yeterli miktarda çöp kutuları yerleștirilmiştir sorusuna katılımcıların \%65,8'i kesinlikle katılıyorum, \%18,4'ü katılıyorum, \%13,2'si kararsızım, \%2,6'sı ise kesinlikle katılmıyorum yanıtını vermişlerdir. Bu yanıtlardan otellerin atıkların türlerine göre ayrıştırılması için gerekli düzenlemeleri yaptığı kanısına varılabilir. Otel içerisinde çeşitli alanlarda atık pil kutuları mevcuttur sorusuna katılımcıların \%73,7'si kesinlikle katılıyorum, \%18,4'ü katılıyorum, \%7,9'u ise kesinlikle katılmıyorum yanıtını vermişlerdir. Bu oranlar da otellerin çoğunda bu adımların atılmış olduğunu ortaya koymaktadır.

Karbon salınımını azaltmak amacıla satın alımlar mümkün olduğunca yakın bölgelerden yapılmaktadır sorusuna katılımcılar \%52,6 kesinlikle katılıyorum, \%44,7 katılıyorum ve \%2,6 kararsızım olarak yanıt vermişlerdir. Bu oranlardan otellerin bu konuda bilinçli hareket ettiği çıkarımı yapılabilir. Daha az karbon enerjileri tercih edilmektedir sorusunu katılımclar \%60,5 kesinlikle katılıyorum, \%18,4 katılıyorum ve \%21,1 kararsızım șeklinde yanıtlamışlardır. Yüzde 21'lik kararsız oranı otellerin bu konuda yol kat etmeleri gerektiğini ortaya koymaktadır. Bisiklet kiralama imkanı verilerek karbon salınımı azaltılmaya çalışılmaktadır sorusuna katılımcıların \%39,5’i 
kesinlikle katılıyorum, \%23.7'si katılıyorum, \%10,5'i kararsızım, \%23,7'si katılmıyorum ve $\% 2,6$ 'sı ise kesinlikle katılmıyorum yanıtını vermişlerdir. Kesinlikle katılmıyorum, katılmıyorum ve kararsızım oranları toplandığında \% 36,8 yapmaktadır. $\mathrm{Bu}$ azımsanmayacak bir orandır, otellere bu konuda kendilerini geliștirmeleri yönünde öneri yapılabilir.

Cevreye en az zarar veren teknoloji kullanılmaktadır sorusuna yöneticiler \%65,8'i kesinlikle katılıyorum, \%23,7'si katılıyorum, \%7,9'u kararsızım ve \%2,6'sı ise katılmıyorum yanıtlarını vermişlerdir. Bu sonuçlara bakıldığında otellerin teknoloji kullanımında çevreyi de göz ardı etmedikleri söylenebilir. Doğaya zarar vermemek için ağaç kesimi yapılmamaktadır sorusuna katılımcıların \%65,8'i kesinlikle katılıyorum, \%26,3’ü katılıyorum, \%7,9’u kararsızım yanıtını vermişlerdir. Bu verilerden otellerin çevreye zarar vermemek adına ağaç kesimi yapmadıkları kanısına varılabilir.

Plajda yeterli sayıda çöp kutusu ve atık konteynırı bulundurulmakta ve düzenli kontrolleri yapılmaktadır sorusuna katılımcıların \%76,3'ü kesinlikle katılıyorum, \%23,7'si katılıyorum yanıtını vermiştir. Bu oranlardan otellerin bu konuda gereken titizliği ve özeni gösterdiği çıkarımı yapılabilir. Deniz dip temizliği yapılmaktadır sorusuna katılımcılar \%47,4 kesinlikle katılıyorum, \%26,3'ü katılıyorum, \%10,5 kararsızım, \%2,6 katılmıyorum, \%13,2 kesinlikle katılmıyorum şeklinde yanıt vermiştir. Kesinlikle katılmıyorum, katılmıyorum ve kararsız oranları toplandığında \% 26,3 yapmaktadır bu oranlar otellerin bu konuda düşünmesi gerektiğini ortaya koymaktadır. Otellerin bu faaliyetleri sorumlu tüketim ve üretim, erişilebilir temiz enerji, insana yakışır iş ve ekonomik büyüme, sürdürülebilir şehir ve yașam alanları, sanayi yenilikçilik ve alt yapı, iklim eylemi, sudaki yaşam ve karasal yaşam gibi sürdürülebilir kalkınma hedeflerini yerine getirme yönünde çalıștıklarını göstermektedir.

\begin{tabular}{|c|c|c|c|c|c|c|}
\hline & 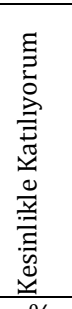 & 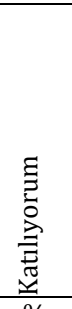 & 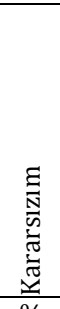 & 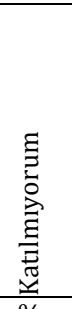 & 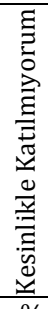 & \multirow[t]{2}{*}{ 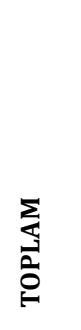 } \\
\hline & $\%$ & $\%$ & $\%$ & $\%$ & $\%$ & \\
\hline $\begin{array}{l}\text { Çalışanlar tasarruf tedbirleri adı altında } \\
\text { eğitilmektedir. }\end{array}$ & 57,9 & 23,7 & 2,6 & 15,8 & - & $\% 100$ \\
\hline $\begin{array}{l}\text { Çalışanlara atık ayrıştırma konusunda eğitimler } \\
\text { verilmektedir. }\end{array}$ & 68,4 & 23,7 & 5,3 & - & 2,6 & $\% 100$ \\
\hline $\begin{array}{l}\text { Doğanın yangınlara maruz kalmaması için } \\
\text { çalışanlar yangın konusunda eğitilmekte ve } \\
\text { yangın tatbikatları düzenlenmektedir. }\end{array}$ & 76,3 & 10,5 & 2,6 & 10,5 & - & $\% 100$ \\
\hline $\begin{array}{l}\text { Paydaşlar çevre konusunda bilinçlendirilerek } \\
\text { doğal kaynaklar korunmaktadır. }\end{array}$ & 63,2 & 23,7 & 7,9 & 2,6 & 2,6 & $\% 100$ \\
\hline $\begin{array}{l}\text { Ortak kullanım alanlarında suyun tasarruflu } \\
\text { kullanılması ve su sızıntısı ve buna benzer } \\
\text { herhangi bir şey olduğunda bildirilmesi yönünde }\end{array}$ & 60,5 & 23,7 & - & 15,8 & - & $\% 100$ \\
\hline
\end{tabular}




\begin{tabular}{|l|l|l|l|l|l|l|}
\hline rica yazıları yazılmıştır & & & & & & \\
\hline $\begin{array}{l}\text { Odalarda misafirlerin odadan ayrıldıklarında } \\
\text { elektrikle çalışan cihazları kapatmaları için uyarı } \\
\text { yazıları bulunmaktadır. }\end{array}$ & 55,3 & 26,3 & 7,9 & 10,5 & - & $\% 100$ \\
\hline $\begin{array}{l}\text { Misafirlere doğaya zarar veren etkinliklere } \\
\text { katılmamaları konusunda bilgilendirici uyarı } \\
\text { yazıları yazılmıștır. }\end{array}$ & 50,0 & 23,7 & 7,9 & 13,2 & 5,3 & $\% 100$ \\
\hline $\begin{array}{l}\text { Çevre duyarlılı̆ı konusunda çocuklara eğitici } \\
\text { etkinlikler düzenlenmektedir. }\end{array}$ & 47,2 & 36,1 & 5,6 & 2,8 & 8,3 & $\% 100$ \\
\hline $\begin{array}{l}\text { Atık ayrıştırma ile ilgili etkilikler düzenlenerek } \\
\text { çocuk misafirler bilinçlendirilmektedir. }\end{array}$ & 41,7 & 36,1 & 16,7 & - & 5,5 & $\% 100$ \\
\hline $\begin{array}{l}\text { Çeşitli çevre etkinlikleri düzenlenerek } \\
\text { çalışanların, yöre halkının ve misafirlerin çevreye } \\
\text { olan duyarlılığı artırılmaya çalışılmaktadır. }\end{array}$ & 44,7 & 31,6 & 5,3 & 10,5 & 7,9 & $\% 100$ \\
\hline
\end{tabular}

Tablo 3. Paydaşları Bilgilendirme, Bilinçlendirme ve Uyarma

Calışanlar tasarruf tedbirleri adı altında eğitilmektedir sorusuna yöneticilerin \%57,9’u kesinlikle katılıyorum, \%23,7'si katılıyorum, \%2,6'sı kararsızım ve \%15,8'i ise katılmıyorum yanıtını vermiş̦tir. Bu verilerden çalışanların tasarruf tedbirleri adı altında eğitildiği çıkarılabilir. Çalışanlar atık ayrıștırma konusunda eğitimler verilmektedir sorusuna ise katılımcıların \%68,4'ü kesinlikle katılıyorum, \%23,7'si katılıyorum, \%5,3'ü kararsızım, \%2,6'sı kesinlikle katılıyorum demiştir. Bu oranlara bakıldığında otellerin çalışanlarının bu konudaki eğitimi konusunda hassasiyet gösterdikleri görülmüştür. Doğayı yangınların zararından korumak için çalışanlar yangın konusunda eğitilmekte ve yangın tatbikatları düzenlenmektedir sorusunu katılımcılar \%76,3'ü kesinlikle katılıyorum, \%10,5'i katılıyorum, \%2,6'sı kararsızım, \%10,5'i katılmıyorum şeklinde yanıtlamışlardır. Paydaşlar çevre konusunda bilinçlendirilerek doğal kaynaklar korunmaktadır sorusu ise \%63,2 kesinlikle katılıyorum, \%23,7 katılıyorum, \%7,9 kararsızım, \%2,6 katılmıyorum ve \%2,6 kesinlikle katılmıyorum șeklinde yanıtlanmıștır. $\mathrm{Bu}$ verilerden otellerin çevre konusunda bilinçlendirme çalışması yaptıkları görülmektedir.

Ortak kullanım alanlarında(WC benzeri) suyun tasarruflu kullanılması, su sızıntısı ve buna benzer herhangi bir șey olduğunda bildirilmesi yönünde rica yazıları yazılmıștır sorusuna katılımcların \%60,5'i kesinlikle katılıyorum, \%23,7'si katılıyorum, \%15,8'i ise katılmıyorum demiştir. Odalarda misafirlerin odadan ayrıldıklarında elektrikle çalışan cihazları kapatması için uyarı yazıları bulunmaktadır sorusuna katılımcıların \%55,3'ü kesinlikle katılıyorum, \%26,3'ü katılıyorum, \%7,9'u kararsızım, \%10,5'i katılmıyorum şeklinde yanıt vermiştir. Bu sonuçlar otellerin bu konuda adım attıklarını göstermektedir. Misafirlere doğaya zarar veren etkinliklere katılmamaları konusunda bilgilendirici uyarı yazıları yazılmıștır \% 50,0 kesinlikle katılıyorum, \%23,7 katılıyorum, \%7,9 kararsızım, \%13,2 katılmıyorum ve \%5,3 kesinlikle katılmıyorum şeklinde yanıtlamışlardır. Çevre duyarlılığı konusunda çocuklara yönelik eğitici etkinlikler düzenlenmektedir sorusuna katılımcıların \%47,2'si kesinlikle katılıyorum, \%36,1'i katılıyorum, \%5,6'sı kararsızım, \%2,8'i katılmıyorum, \% 8,3'ü kesinlikle katılmıyorum yanıtını vermiştir. Katılımcıların \%5,3’ü ise bu soruyu yanıtsız bırakmıştır. Bu veriler ele 
alındığında otellerin çocuklara yönelik çevre etkinlikleri düzenleyerek çocukları çevre konusunda bilinçlendirdikleri söylenebilir. Atık ayrıştırma ile ilgili aktiviteler düzenlenerek çocuk misafirlerin bilinçlenmesi sağlanmaktadır sorusuna katılımcıların \% 41,7'si kesinlikle katılıyorum, \%36,1'i katılıyorum, \%16,7'si kararsızım, \%5,5'i ise kesinlikle katılmıyorum yanıtını vermişlerdir. Anket sorusuna ilişkin yanıtlara bakıldığında otellerin çocuklara yönelik atık ayrıştırma aktiviteleri düzenlendikleri çıkarılabilir. Çeşitli çevre etkinlikleri düzenlenerek çalışanların, yöre halkının ve misafirlerin çevreye olan duyarlılı̆̆ı artırılmaya çalışılmaktadır sorusuna katılımcıların \%44,7'si kesinlikle katılıyorum, \%31,6'sı katılıyorum, \%5,3'ü kararsızım, \%10,5'i katılmıyorum, \%7,9'u ise kesinlikle katılmıyorum yanıtını vermiştir. Tabloya bakıldığında otellerin çoğunun çevre etkinlikleri konusunda yeterli duyarlılığa sahip oldukları öne sürülebilir. Ayrıca bu adımlar otellerin sürdürülebilir kalkınmanın nitelikli eğitim hedefini gerçekleștirme yönünde ortaya koydukları önemli örneklerdir.

\begin{tabular}{|c|c|c|c|c|c|c|}
\hline Risk Yönetimi & 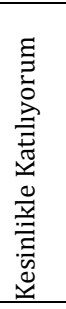 & 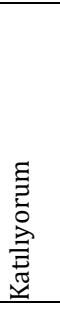 & 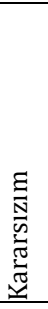 & 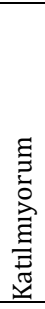 & 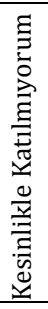 & \multirow{2}{*}{$\sum_{\substack{1 \\
\vdots \\
0}}$} \\
\hline & $\%$ & $\%$ & $\%$ & $\%$ & $\%$ & \\
\hline $\begin{array}{l}\text { Sağllk, güvenlik, çevre bütünlüğü } \\
\text { bağlamında oluşabilecek riskler } \\
\text { önceden belirlenerek önlem } \\
\text { alınmaktadır. }\end{array}$ & 76,3 & 23,7 & - & - & - & $\% 100$ \\
\hline
\end{tabular}

Tablo 4. Risk Yönetimi

Risk yönetimi zarara uğrama olasılı̆̆ını ortadan kaldıran vazgeçilmez bir yoldur. Otellerin riskleri belirleyip gerekli önlemleri almaları diğer bir deyişle risk yönetimi yapmaları onların yașam evrelerini uzatacak bir uygulamadır.

\section{Sonuç ve değerlendirme}

$\mathrm{Bu}$ çalışmada sürdürülebilir kalkınma çağında kurumların sürdürülebilirlik yaklaşımları sürdürülebilir kalkınmanın ekonomik, çevresel ve ufak da olsa sosyal boyutu(cinsiyet oranı, bilgilendirme, bilinçlendirme ve uyarma) temelinde oteller üzerinden ortaya koyulmaya çalışılmıştır. Bu bağlamda da Holidaycheck'in 2017 Yılının En Iyi Otellerini Listesi'ne Türkiye'den giren 19 otelin yöneticilerinin yanıtlaması için bir anket formu hazırlanmış ve otel yöneticileriyle iletişime geçilmiştir. Bu veriler sonucu otellerin sürdürülebilir kalkınmanın ekonomik ve çevresel boyutu temelinde önemli adımlar attıkları görülmüştür. Katılımcıların \%42,1'i (16) kadın, \%57,9'u (22) erkek olması erkeklerin sayıca fazla olmasının yanında aradaki rakamların düşük olması 
otellerin kalkınma hedeflerinden toplumsal cinsiyet eșitliği yönünde adım attıklarını kanıtlar niteliktedir. Otellerin kullandıkları malzemelerin tehlikeli madde içermemesine dikkat etmeleri ve tehlikeli madde içeren malzemeleri bertaraf etmeleri de dikkat çekicidir. Otellerin ürün satın alınırken enerji verimliliğini önemsemeleri, kurumlarında bulunan ve satın alınan tüm elektronik ürünlerin enerji tasarruflu olması, odalarda balkon kapısı açıldığı zaman ısıtma-soğutma cihazlarını devre dışı bırakan sistemlerin mevcudiyeti, enerji tasarruflu ampuller ya da LED ışıkların kullanılması, ışıklandırma sisteminin harekete duyarlı hale getirilmesi,kimsenin bulunmadığı alanlarda hareket olmadığı için ışıkların otomatik olarak sönmesinin sağlanması ve misafirler odalarından ayrıldıklarında elektrik sistemlerinin otomatik olarak kapanmasını sağlayan kart sistemleri kullanılması önemli sonuçlardır. Tüm bunlar otellerin sürdürülebilir kalkınma hedeflerinden sorumlu tüketim ve üretim yönünde adım attıklarını ortaya koymaktadır. Ayrıca elde edilen bu veriler otellerin sürdürülebilir kalkınmanın ekonomik boyutunu ortaya koyan mal ve hizmetleri doğal kaynakların aşırı tüketimini engelleyerek üreten, sürdürülebilir bir sistemi kurduklarını göstermektedir. Ayrıca otellerin sıcak su ihtiyacının giderilmesinde güneş enerjisinden faydalanılması, bahçe sulamalarında fiskiye ve damlama sistemlerinin kullanılarak suyun daha az kullanılması ve boşa akıtılmaması, kağıt tüketimini azaltmak için yazışmaların ve duyuruların mail yoluyla sağlanması göze çarpan diğer unsurlardır. Bunun yanında çevreye verilecek zararı minimize etmek için tehlikeli atık oluşumuna neden olacak sistemlerin azaltılmaya çalışılması, oluşan atıkların hem çalışanların hem de misafirlerin desteği ile kağıt, plastik, metal veya cam olarak ayrıştırılıp doğaya geri kazandırılması, atık suların arıtılarak deşarj edilmesi ve kanalizasyon sistemine gönderilmesi, misafirlerin atıkları ayrıştırabilmeleri için yeterli miktarda çöp kutularının gerekli alanlara yerleștirilmesi, çeşitli alanlarda atık pil kutularının bulunması, karbon salınımını azaltmak için satın alımların yakın bölgelerden yapılmaya çalışılması,müşterilere bisiklet kiralama imkanı verilmesi, daha az karbon enerjilerin tercih edilmesi, çevreye zarar vermemek için ağaç kesiminin yapılmaması gibi sonuçlar özellikle çevresel anlamda dikkate değerdir. Bu verilerde otellerin, sürdürülebilir kalkınma hedeflerinden sorumlu tüketim ve üretim, erişilebilir temiz enerji, insana yakıșır iş ve ekonomik büyüme, sürdürülebilir şehir ve yaşam alanları, sanayi yenilikçilik ve alt yapı, iklim eylemi, sudaki yaşam ve karasal yaşam gibi hedefler yönünde çalıștıklarını kanıtlamaktadır. Bunun yanında bu veriler, otellerin sürdürülebilir kalkınmanın çevresel boyutunu ortaya koyan kendi kaynaklarını yönetebilen ve çevreye zarar vermeden bunu yapan bir sistem konusunda yol kat ettiklerini de göstermektedir. Üstelik otellerin plaj temizliği ve deniz dip temizliği konusunda adımlarının olması da çarpıcıdır. Otellerin bu adımları sürdürülebilir kalkınma hedeflerinden sudaki yaşam ve karasal yaşam hedeflerini gerçekleștirdiklerini göstermektedir. Ayrıca çalışanların tasarruf, atık ayrıştırma, yangın konularında eğitilmesi, çocuklara yönelik çevre ve atık ayrıştırma konularında bilinçlendirme eğitimleri yapılması da otellerin bu konudaki üstün yönlerini ortaya koymaktadır. Bunlara ek olarak misafirler ve çalışanlar için ortak kullanım alanlarında suyun tasarruflu kullanılması ve su sızıntısı veya buna benzer herhangi bir şey olduğunda bildirmeleri yönünde rica yazılarının yazılması, çeşitli çevre etkinlikleri düzenlenerek çalışanların, yöre halkının ve misafirlerin çevreye olan duyarlılığının artırılmaya 
çalışılması, misafirlere doğaya zarar veren etkinliklere katılmamaları konusunda bilgilendirici uyarı yazıları hazırlanması sürdürülebilir yaşam açısından fırsatlar sunan yöntemler olarak algılanmaktadır. Bu faaliyetler, aynı zamanda otellerin sürdürülebilir kalkınmanın nitelikli eğitim hedefini gerçekleștirme adımlarıdır. Bunun yanında bu yönde yapılan çalışmalardan Santos ve Figueroa'nın araştırmasında ortaya koyulan bazı başlıklar arıtma sistemi, ağaç dikimi, atıksu arıtma, enerji tasarrufu ve tüketici bilinci yaratma gibi konular makalemizde de değindiğimiz konularla örtüşmektedir. Ayrıca Hoyer'in çalışmasında önerdiği yaklaşım burada da öneri olarak tekrarlanabilir. Sürdürülebilir turizmin sürdürülebilir bir hareketlilik konseptiyle ilişkilendirilmesi bunun için turizm işletmeleri ve devletin önlem alması önerisi yapılabilir. Örnek olarak örneklem içerisinde yer alan bir otelin herhangi bir yasal engel olmadığı halde daha az yatak ve daha az oda sayısı politikası güderek sürdürülebilir alanda somut adımlar atması gösterilebilir. Turizm alanında faaliyet gösteren Holidaycheck'in 2017 yılının en iyi otellerini listesine Türkiye'den giren 19 otelin yöneticilerinin görüşleri doğrultusunda kurumların sürdürülebilir alanda attıkları adımları ortaya koyan bu çalışma bu açıdan sınırlıdır. Araştırmacılar farklı sektörlerdeki kurum yöneticileriyle de bu tarz çalışmalar ortaya koyabilirler. Veya Holidaycheck Listesi'ne giren yabancı otellerle yapılacak bu yönde çalışmaların ve ülkeler arası karşılaştırmaların alana daha pozitif katkılar sunacağı düşünülmektedir. Yine bu çalışmada sürdürülebilir kalkınmanın sosyal boyutu eksiktir, araştırmacılar yoksulluğa ve açlığa son, toplumsal cinsiyet eşitliği, barış ve adalet, eşitsiliklerin azaltılması gibi sürdürülebilir kalkınmanın toplumsal hedeflerini daha derinlemesine inceleyen ayrıntılı çalışmalar ortaya koyabilirler.

\section{KAYNAKÇA}

ANAND, S. \& SEN, A. K. (1996). Sustainable human development: concepts and priorities, undp discussion paper series; Sürdürülebilirlik için İletişim- Sürdürülebilir Üretim ve Tüketim Yayınları- 2011, Çevre ve Şehircilik Bakanlığı.

BAUM, Tom (2018). Sustainable human resource management as a driver in tourism policy and planning: a serious sin of omission? Journal of Sustainable Tourism, Volume 26, İssue 6, 873-889.

BOZLAĞAN, R. (2005). Sürdürülebilir gelişme düşüncesinin tarihsel arka planı", Sosyal Siyaset Konferansları Dergisi, İstanbul Üniversitesi, İktisat Fakültesi Yayını, 50, 1011-1028.

BRAMWELL, Bill \& LANE, Bernard (1999) Sustainable Tourism: Contributing to the Debates, Journal of Sustainable Tourism, 7:1, 1-5,

CANPOLAT, Nesrin vd.(2015) "Sürdürülebilir kalkınma çağında kurumsal iletişim"çağdaş pazarlamada yeni yaklaşımlar, Ed. Murat Toksarı ve Murat Akın, Paradigma Akademi Yayınları.

CHOI, H. C., \& SIRAKAYA, E. (2006). Sustainability indicators for managing community tourism. Tourism Management, 27, 1274-1289 
Nesrin Canpolat, Ebru Öztürk, “Sürdürülebilir Kalkınma Çağında Kurumların Sürdürülebilirlik Yaklaşımı: Oteller Üzerinden Bir Değerlendirme”, İstanbul Gelişim Üniversitesi Sosyal Bilimler Dergisi, 6 (1), Nisan 2019, ss. 18-36

CLARKE, J. (1997). A framework of approaches to sustainable tourism. Journal of Sustainable Tourism, 5, 224-233.

ÇENGEL BABACAN, Birsen (2013). Kapadokya bölgesi'ndeki butik otellerde konaklama nedenlerine yönelik bir araştirma, Yüksek Lisan Tezi, Niğde: Niğde Ömer Halisdemir Üniversitesi.

DEMIRBULAT Ö. G. ve DINÇ N. T. (2017). Sürdürülebilir turizm konulu lisansüstü tezlerin bibliyometrik profili, Seyehat ve Otel İşletmeciliği Dergisi, 14 (2), 20-30.

GODFREY, K. B. (1998). Attitudes towards 'sustainable tourism' in the UK: A view from local government. Tourism Management, 19, 213-224.

HOROBIN, H., \& LONG, J. (1996). Sustainable tourism: The role of the small firm. International Journal of Contemporary Hospitality Management, 8, 15-19

HØYER, K. J. (2000). Sustainable tourism or sustainable mobility? The Norwegian case Journal of Sustainable Tourism, 8, 147.

IRANDU, E. V. (2006). Sustainable tourism development on Kenya's Coast: A hospitality sector view. Sustainable Tourism Development on Kenya's Coast: A Hospitality Sector View, 17, 189-209.

KAYAALP, T. ve TOPRAK D. (2011). Sürdürülebilirlik için iletişim- Sürdürülebilir Üretim ve Tüketim Yayınları, Çevre Șehircilik Bakanlığı Yayını.

MATOS, S. ve SILVESTRE, B. S. (2013). Managing stakeholder relations when developing sustainable business model: the case of the brazilian energy sector, Journal of Cleaner Production, 45, 61-73.

OLTMANNS, R. (2008). Enviromental crisis communications, Practical PR Strategies for Reputaion Management and Company Survival, 157-175.

ÖZMEHMET, E. (2012). Dünyada ve türkiye'de sürdürülebilir kalkınma yaklaşımları, Yaşar Üniversitesi Dergisi, Sayı 12, Cilt 3, 1-23.

YILMAZ. İ. A., ÜNAL A., ÇAKIR G. (2015). Sürdürülebilir turizm literatürü üzerine bir değerlendirme: türkiye bağlamı, Mesleki Bilimler Dergisi, 4(2), 55-83.

\section{Summary}

Sustainable development puts forward the process of considering the relationship between economic, environmental and social parameters in the running of institutions. In this context, in the sustainable development age institutions' sustainability approach bears importance. Especially institutions in tourism field which are fed on environmental elements should consider the relationship between economic, environmental and social parameters in their running. Because tourism uses environmental elements more compared to other fields and environment is one of the most important element that affects touristic demands. This study aims to put forward the economical dimension (a sustainable system that produces its goods and services by preventing the overconsumption of natural sources) and environmental dimension (a system that manages its own resources and conducts this without harming the environment) on the basis of sustainable development of hotels' sustainability approaches operating in tourism field. Social dimension of sustainable development expresses a system that oversees income 
and gender equality, has political reliability and gives importance to participation. However, in this study social dimension is scrutinized on the basis of informing and raising awareness dimension of hotel shareholders. Other social parameters were not discussed, those parameters are subjects that should be researched independently. Researchers can study on this subject. In this context, a survey form was sent to managers of 19 hotels that were in the best hotels of 2017 in Holidaycheck from Turkey. Survey questions were formed from studies as a result of literature search, data that were collected as a result of examination of Sustainability Reports of 30 Turkish Companies Member of Global Compact in 2014 by Canpolat et al. and Sustainability Reports. Face validity by consulting colleagues, content validity by consulting experts and Cronbach alpha values were calculated. In the findings of the views of hotel managers' towards hotels' sustainability steps, when an analysis was conducted for 38 items, it is observed that obtained Cronbach Alpha Value is 0,968.

Survey consists of two parts under the topics of personal information and qualities of the hotel. In the personal information part there are 7 close-ended questions and in the qualities of the hotel part there are 38 items organized with 5 point likert scale that is thought to pit the hotels' sustainability approaches. This survey was sent to managers in every rank to 19 hotels that are in the List of Holidaycheck from Turkey in 2017. Interviews began in February 15, 2018 and communication process lasted until May 20, 2018 for hotels to answer their surveys. Communication was conducted through facebook, e-mail and phone calls. Only 12 hotels agreed to participate in the survey among 19 hotels. Surveys were answered by 38 managers of 12 hotels. Surveys that are answered by hotel managers were evaluated by using SPSS program and descriptive percentage analysis were performed. As a result of these data it was observed that hotels took important steps on the basis of economic and environmental dimension of sustainable development. Some topics that were put forward in the study of Santos and Figueroa such as purifying system, planting trees, wastewater treatment, energy saving and creating consumer awareness overlap with the subjects we have touched upon. Furthermore, the approach Hoyer suggested in her study can be repeated as a suggestion here. Associating sustainable tourism with a sustainable mobility concept and for this tourism establishments and government can be suggested to take precautions. Although there is not any legal barrier, a hotel in the sample adopt a policy of less bed and less room and this can be shown as an example for taking concrete steps in sustainable field. This study which put forwards the steps institutions take in sustainable field in terms of the views of managers of 19 hotels that are in the list of best hotels in Holidaycheck's list in 2017 from Turkey is limited in this aspect. Researchers can put forward studies in this style with institution managers in different fields. Or it is thought that studies that would be conducted with foreign hotels in Holidaycheck List and international comparisons will contribute more to the field. 